Jurnal BASTRA (Bahasa dan Sastra) : http://ojs.uho.ac.id/index.php/BASTRA

\title{
MAKSIM KESANTUNAN BERBAHASA WAWONII
}

\section{OLEH}

\author{
Pita Delima $^{1}$, Zalili Sailan ${ }^{2}$, dan La Yani Konisi ${ }^{3}$ \\ ${ }^{1}$ Alumni Jurusan Pend. Bahasa dan Sastra Indonesia, ${ }^{2,3}$ Dosen Jurusan Pendidikan \\ Bahasa dan Sastra Indonesia, Fakultas Keguruan dan Ilmu Pendidikan \\ Universitas Halu Oleo
}

\begin{abstract}
ABSTRAK
Maksim Kesantunan Berbahasa Wawonii yang dilakukan di Desa Munse Kecamatan Wawonii Timur, penulisan ini dilatarbelakangi penggunaan bahasa daerah yang saat ini kerap menggunakan bahasa-bahasa yang dinilai kurang santun. Rumusan masalah dalam penelitian ini yaitu bagaimana kesantunan berbahasa masyarakat Wawonii yang berkaitan dengan maksim-maksim kesantunan berbahasa. Tujuan yang ingin dicapai dari penelitian ini adalah untuk memberikan gambarangambaran penggunaan maksim kesantunan berbahasa Wawonii di Desa Munse Kecamatan Wawonii Timur. Penelitian ini menggunakan metode deskriptif kualitatif. Teknik pengumpulan data dalam penelitian ini dilakukan dengan teknik cakap semuka, yaitu, langsung mengetahui kondisi geografis setiap daerah pengamatan yang mungkin turut berperan bagi perkembangan isolek pada daerah pengamatan itu sendiri. Teknik catat, yaitu teknik yang digunakan dengan cara mencatat percakapan dan teknik rekam yaitu teknik yang digunakan untuk merekam percakapan seluruh pembicaraan informan dilingkungan Desa Munse Kecamatan Wawonii Timur. Dari hasil penelitian yang dilakukan mengenai Maksim Kesantunan Berbahasa Wawonii di Desa Munse Kecamatan Wawonii Timur maka penulis dapat menyimpulkan bahwa ditemukan gambaran-ganbaran penggunaan maksim berbahasa Wawonii di lingkungan Desa Munse Kecamatan Wawonii Timur menggunakan maksim kesantunan berbahasa, maksim kesantunan yang dimaksud yaitu maksim kebijaksanaan, maksim kedermawanan, maksim pujian, maksim perendahan hati, maksim kesetujuan, maksim kesimpatian, maksim pertimbangan.
\end{abstract}

Kata Kunci: maksim, kesantuan, berbahasa 


\section{PENDAHULUAN}

\subsection{Latar Belakang}

Bahasa merupakan alat komunikasi yang paling utama. Karena bahasa tidak dapat dipisahkan dari kehidupan manusia sebagai alat interaksi dengan yang lainnya. Komunikasi akan berjalan lancar apabila sasaran bahasa yang digunakan tepat, artinya bahasa itu dipergunakan sesuai dengan situasi dan kondisi penutur dan sifat pertuturan itu dilaksanakan. Hal ini sangat bergantung pada faktor-faktor penentu dalam tindak bahasa atau tindak komunikasi, yaitu lawan bicara, tujuan pembicara, masalah yang dibicarakan, dan situasi.

Peranan bahasa daerah sangat mendukung bagi masyarakat penuturnya. Hal tersebut dapat dilihat dari berbagai aktifitas masyarakat pendukung bahasa daerah itu yang senantiasa menjadikan bahasa daerah sebagai alat untuk mencapai tujuan yang telah dirumuskan. Selain itu, dalam proses penyelenggaraan upacara-upacara adat disuatu daerah dan bentuk kesenian lainnya yang tetap hidup dan terpelihara oleh masyarakat yang bersangkutan di daerah yang tidak dapat dipisahkan dengan penggunaan bahasa daerah.

Secara formal, kebijakan mengenai bahasa daerah tertuang dalam penjelasan pasal 36 UndangUndang dasar 1945, yakni di daerahdaerah yang mempunyai bahasa yang dipelihara oleh rakyatnya dengan baikbaik (misalnya Bahasa Sunda, Jawa, Madura dan sebagainya) akan dihormati dan dipelihara oleh Negara. Penjelasan tersebut menunjukkan adanya hasrat untuk memelihara bahasa daerah dan hasrat untuk mendudukipersoalan bahasa daerah di lingkungan Negara Republik Indonesia.

Bahasa daerah Wawonii merupakan satu di antara jenis bahasa daerah yang ada di Negara Republik Indonesia. Berdasarkan pernyataan tentang pelestarian dan perlindungan bahasa daerah, maka perlulah diadakannya penelitian dan pengkajian yang sistematis mengenai bahasa tersebut. Keberadaan bahasa daerah Wawonii akan memberikan kontribusi penting terhadap pelestarian budaya bangsa. Bahasa Wawonii adalah bahasa daerah yang berada di wilayah Sulawesi Tenggaara.Bahasa tersebut digunakan oleh masyarakat Sulawesi Tenggara, khususnya masyarakat yang berdomisili di Desa Munse, Kecamatan Wawonii Timur Kabupaten Konawe Kepulauan.

Sebagai upaya pelestarian bahasa daerah yang berada dan digunakan oleh masyarakat Sulawesi Tenggara, khususnya bahasa Wawonii telah dilakukan penelitian oleh $\mathrm{La}$ Ino. Penelitian tersebut mengkaji "Morfofonemis Bahasa Wawonii" dan diteliti pula oleh Feri Irawan yang mengkaji "Struktur Klausa Verba Bahasa Wawonii". Penelitian tersebut belum sepenuhnya mengkaji atau menjelaskan aspek-aspek kebahasaan Bahasa Wawonii, sehingga perlu adanya penelitian lanjutan yang dapat memberi hasil penelitian yang baru (alamiah) menyangkut masalah tersebut. Dari berbagai aspek kebahasaan yang belum dijelaskan dalam penelitian tersebut satu di antaranya adalah aspek pragmatik, khususnya mengenai maksim kesantunan berbahasa Wawonii.

Penutur bahasa daerah sekarang kurang memperhatikan maksim kesantunan dalam berbahasa. Hal ini disebabkan oleh faktor terbatasnya 
pengetahuan penutur yang meliputi (1) pentingnya memahami kesantunan dalam berbahasa (2) prinsip kesantunan dalam berbahasa, dan (3) konteks berbahasa. Dalam penggunaan bahasa wawonii pun seringkali masyarakat Wawonii di Desa Munse Kecamatan Wawonii Timur di pengaruhi oleh bahasa Indonesia. Pengaruh-pengaruh tersebut tentu saja memberikan dampak bagi penggunaan bahasa daerah. Masyarakat Desa Munse saat ini kerap menggunakan bahasa-bahasa yang saat ini dinilai kurang sopan, misalnya saat bertemu dengan seorang yang lebih tua umurnya, Koam tanta? 'Pergi mana tante?' yang sebaiknya menggunakan kata Maina lakoa miu tanta? 'Mau pergi kemana tante?'

Memang tidak ada yang berhak melarang, menyalahkan dan mengatur seseorang untuk mengungkapkan sesuatu, tetapi diketahui bahwa bangsa Indonesia dikenal dengan budaya santun dalam bahasanya, hal tersebut merupakan sifat alamiah setiap suku bangsa di Indonesia termasuk bahasa Wawonii. Sehingga, perlunya mengajak kembali penutur-penutur bahasa Wawonii untuk memperhatikan dan memahami penggunaan bahasa yang santun dalam berbahasa Wawonii.

\subsection{RumusanMasalah}

Berdasarkan uraian latar belakang, dapat diperoleh suatu rumusan masalah dalam penelitian ini adalah:

1. Bagaimana kesantunan berbahasa masyarakat Wawonii yang berkaitan dengan maksim kebijaksanaan?

2. Bagaimana kesantunan berbahasa masyarakat Wawonii yang berkaitan dengan maksim kedermawanan?
3. Bagaimana kesantunan berbahasa masyarakat Wawonii yang berkaitan dengan maksim pujian?

4. Bagaimana kesantunan berbahasa masyarakat Wawonii yang berkaitan dengan maksim perendahan hati?

5. Bagaimana kesantunan berbahasa masyarakat Wawonii yang berkaitan dengan maksim kesetujuan?

6. Bagaimana kesantunan berbahasa masyarakat Wawonii yang berkaitan dengan maksim kesimpatian?

7. Bagaimana kesantunan berbahasa masyarakat Wawonii yang berkaitan dengan maksim pertimbangan?

\section{Tujuan Penelitian}

Tujuan yang ingin dicapai dalam penelitian ini adalah.

1. Untuk memberikan gambarangambaran penggunaan maksim kebijaksanaan dalam Bahasa Wawonii.

2. Untuk memberikan gambarangambaran penggunaan maksim kedermawanan dalam Bahasa Wawonii.

3. Untuk memberikan gambarangambaran penggunaan maksim pujian dalam Bahasa Wawonii.

4. Untuk memberikan gambarangambaran penggunaan maksim perendahan hati dalam Bahasa Wawonii.

5. Untuk memberikan gambarangambaran penggunaan maksim kesetujuan dalam Bahasa Wawonii.

6. Untuk memberikan gambarangambaran penggunaan maksim 
kesimpatian dalam Bahasa Wawonii.

7. Untuk memberikan gambarangambaran penggunaan maksim pertimbangan dalam Bahasa Wawonii.

\subsection{Manfaat Penilitian}

Penelitian ini membahas tentang bentuk-bentuk maksim kesantunan berbahasa menurut Leech yang sesuai dalam bahasa Wawonii. Peneliti mengharapkan hasil penelitian ini dapat memberikan gambaran yang rinci dan mendalam tentang bentuk maksim kesantunan dalam bahasa wawonii, sehingga dapat memberikan gambaran dan pemahaman pengkajian pragmatik khususnya pragmatik Bahasa Wawonii.

Selain itu, manfaat lain yang diharapkan peneliti dalam penelitian ini adalah:

1. Dapat dijadikan sebagai sumbangsi pikiran dalam upaya pengembangan dan pembinaan bahasa, khususnya Bahasa Wawonii.

2. Dapat dijadikan sebagai data kebahasaan, terutama mengenai maksim kesantunan Berbahasa Wawonii di Desa Munse Kecamatan Wawonii Timur.

3. Sebagai bahan rujukan atau perbandingan bagi penelitian selanjutnya yang relevan dengan penelitian ini.

\section{KAJIAN PUSTAKA}

\subsection{Sosiolinguistik}

Sosiolinguistik lazim didefinisikan sebagai ilmu yang mempelajari ciri dan berbagai variasi bahasa, serta hunungan diantara para bahasawan dengan ciri fungsi variasi bahasa itu di dalam suatu masyarakat bahasa. Kridalaksana (dalam Chaer dan
Agustina, 2010: 3). Pengkajian bahasa dengan dimensi kemasyarakatan disebut sosiolinguistik. Nababan (dalam Chaer dan Agustina, 2010: 3). Sosiolinguistik adalah kajian tentang ciri khas variasi bahasa, fungsi-fungsi variasi bahasa, dan pemakai bahasa karena ketiga unsur ini selalu berinteraksi, berubah, dan saling mengubah satu sama lain dalam satu masyarakat tutur. Fishman (dalam Chaer dan Agustina, 2010: 3). Sosiolinguistik adalah pengembangan subbidang linguistik yang memfokuskan penelitian pada variasi ujaran, serta mengkajinya dalam suatu konteks sosial. Sosiolinguistik" meneliti korelasi antara vaktor sosial itu dengan variasi bahasa. Hickerson (dalam Chaer dan Agustina, 2010: 4)

Tujuh dimensi dalam yang merupakan masalah dalam sosiolingustik (1) identitas sosial dari penutur, (2) identitas sosial dari pendengar yang terlibaat daalam proses komunikasi, (3) lingkungan sosial tempat peristiwa tutur terjadi, (4) analisis sinkronik dan diaakronik dari daari dialek-dialek sosial, (5) penilaian sosial yang berbeda oleh penutur akan perilaku bentuk-bentuk ujaran, (6) tingkatan variasi dan ragam linguistik, dan (7) penerapan praktis dari penelitian sosiolinguistik. Ditmar (dalam Chaer dan Agustina, 2010: 5)

Dari beberapa pengertian pragmatik yang disampaikan oleh para ahli dapat disimpulkan bahwa sosiolinguistik adalah kajian mengenai ciri dan variasi bahasa yang digunakan dalam suatu masyarakat.

\subsection{Hakikat Pragmatik}

Pragmatik adalah studi tentang hubungan antara bentuk-bentuk linguistik dan pemakai bentuk-bentuk itu. Manfaat belajar bahasa melalui 
pragmatik ialah bahwa seseorang dapat bertutur kata tentang makna yang dimaksudkan orang., asumsi mereka, maksud atau tujuan mereka. Jadi, pragmatik itu menarik karena melibatkan bagaimana orang saling memahami satu sama lain secara linguistik, tetapi pragmatik juga dapat merupakan ruang lingkup studi yang mematahkan semangat karena studi ini mengharuskan kita untuk memahami orang lain dan apa yang dalam pikiran mereka. Yule, (2014: 5-6). Menurut Rahardi (2005: 49) pragmatik adalah ilmu bahasa yang mempelajari kondisi penggunaan bahasa manusia yang pada dasarnya sangat ditentukan oleh konteks yang mewadahi dan melatarbelakangi bahasa itu.

Sehubungan dengan bermacammacam maksud yang mungkin dikomunikasikan oleh penutur, Leech (dalam Rahardi, 2005:50) mengemukakan sejumlah aspek yang senantiasa harus dipertimbangkan dalam pragmatik, yaitu (1) penutur dan lawan tutur, (2) konteks tuturan, (3) tujuan tuturan, (4) tuturan sebagai bentuk tindakan atau aktivitas, (5) tuturan sebagai produk tindak verbal. Kelima aspek tersebut saling melengkapi untuk menganalisis suatu tuturan dalam pragmatik.

Dari beberapa pengertian pragmatik yang disampaikan oleh para ahli dapat disimpulkan bahwa pragmatik adalah kajian mengenai bagaimana bahasa digunakan untuk berkomunikasi, terutama hubungan antara kalimat dengan konteks dan situasi pemakaiannya.

\subsection{Tindak Tutur}

Menurut Austin (dalam Tarigan, 2015: 34) tindak ujar/tindak tutur terdiri atas.
1. Tindak lokusi (melakukan sesuatu untuk menyatakan sesuatu).

2. Tindak ilokusi (melakukan suatu tindakan dalam menyatakan sesuatu).

3. Tindak perlokusi (melakukan suatu tindakan dengan menyatakan sesuatu).

Leech (dalam tarigan 2015: 35) menjelaskan bahwa tindak tutur dapat dibagi menjadi tiga yakni (1) tindak lokusi adalah melakukan tindakan untuk menyatakan sesuatu, contoh: $P a$ berkata kepada Pk bahwa X (2) tindak ilokusi adalah melakukan suatu tindakan dalam mengatakan sesuatu, contoh: Dalam mengatakan $\mathrm{X}, \mathrm{Pa}$ menyatakan bahwa $P$ (3) tindak perlokusi adalah melakukan suatu tindakan dengan menyatakan sesuatu, contoh: Dengan mengatakan $\mathrm{X}, \mathrm{Pa}$ meyakinkan Pa bahwa $P$.

Sebelum membicarakan tentang maksim kesantunan, maka hal yang penting harus dipahami yaitu tindak ilokusi. Tindak ilokusi yang dimaksud adalah tindak ilokusi berdasarkan kriteria tujuan pembicaraan (fungsi pembicara).selain itu hal-hal yang perlu dipahami adalah kebijaksanaan sebagai jenis kesantunan, paradoks pragmatik, dan skala-skala pragmatik. Hal- hal tersebut di uraikan dengan berikut.

J.R Sarle (dalam Tarigan, 2015: 42-45) mengklasifikasikan tindak ilokusi berdasarkan kriteria seperti berikut ini: (a) Asersif, tuturan yang melibatkan pembicara pada kebenaran proposisi yang diekspresikan, misalnya:menyatakan,memberitahuka, menyarankan, membanggakan, mengeluh, menuntut, melapotkan. Ilokusi-ilokusi yang seperti ini cenderung bersifat netral dari segi kesopansantunan, dengan demikian dapat dimasukkan dalam kategori 
kolaboratif. Namun ada beberapa pengecualian,misalnyamembanggakan, menyombongkan yang pada umumnya dianggap tidak sopan. (b) Direktif, dimaksudkan untuk menimbulkan beberapa efek melalui tindakan sang penyimak, misalnya: memesan, memerintahkan, memohon, meminta, menyarankan,menganjurkan,menasihat kan. (c) Komisif, melibatkanpembicara dalam beberapa tindakanyang akan datang, misalnya: menjanjikan, bersumpah,menawarkan, memanjatkan (doa). Dilaksanakan justru lebih memenuhi minat seseorang daripada sang pembicara. (d) Ekspresif, mempunyai fungsi untuk mengekspresikan, mengungkapkan atau memberitahukan sikap psikologis sang pembicara menuju suatu pernyataan keadaan yang diperkirakan oleh ilokusi, misalnya: mengucapkan terima kasih, mengucapkan selamat, memaafkan, mengampuni, menyalahkan, memuji, menyatakan belasungkawa, dan sebagainya. (e) Deklaratif, adalah ilokusi yang bila performansinya berhasil akan menyebabkan korespondensi yang baik antara isi proposisional dengan realitas. Contoh: menyerahkan diri, memecat, membebaskan, membaptis, memberi nama, mengucilkan, mengangkat, menunjuk, menentukan, menjatuhkan hukuman, menvonis dan sebagainya.

\subsection{Kesantunan Berbahasa}

Kesantuanan berbahasa adalah stretegi berbahasa yang digunakan oleh penutur untuk membangun hubungan sosial dalam proses komunikasi. Kesantunan berbahasa dijumpai dalam berbagai masyarakat bahasa, walaupun kesantunan berbahasa yang dimiliki oleh masyarakat itu berbeda-beda sesuai dengan kultur dan budaya yang berlaku. Karena itu kesantunan berbahasa sesungguhnya merupakan fenomena kultural, sehingga apa yang dianggap santun oleh suatu kultur, mungkin tidak demikian halnya dengan kultur yang lain. Esensi dari kesantunan berbahasa, selain untuk membangun hubungan sosial, juga digunakan oleh masyarakat penutur bahasa yang bersangkutan untuk menilai kesantunan orang lain. sebagai fenomena kultural, maka ada banyak hal yang ikut menentukan agar bahasa yang digunakan itu terkesan santun. Dell Hymes (dalam Sailan 2014: 12)

Brown dan Levinson melihat kesantunan sebagai salah satu untuk menghindari konflik. Menurut mereka, kesantunan merupakan dasar dalam struktur kehidupan sosial dalam masyarakat yang mewakili pengungkapan hubungan sosial melalui bahasa. Hal tersebut dimaksudkan untuk mengurangi ketegangan yang timbul dari tujuan komunikatif yang mempertentangkan kebutuhan-kebutuhan sosial dan status. Kesantunan juga menunjukkan kebutuhan sosial untuk mengontrol potensi agresi yang mungkin terjadi didalam satu kelompok masyarakat. Eelen (dalam Sailan 2014: 21)

Berdasarkan pendapat para ahli yang disampaikan dapat disimpulkan kesantunan merupakan aspek kebahasaan yang amat pentinng karena dapat memperlancar interaksi antar individu. Kesantunan pada dasarnya adalah strategi yang dipakai untuk menghindari tindakan mengancam martabat atau muka.

\subsection{Maksim Kesantunan Berbahasa}

Penutur menyakini bahwa dengan bertutur sopan santun kepada lawan bicara, mereka dapat berkomunikasi dengan baik serta dapat menciptakan 
hubungan kekeluargaan yang harmonis penutur juga yakin bahwa dengan bertutur kata yang sopan dan menghindarkan sikap kebencian, ketersinggungan, dan perasaan saling memandang rendah antara peserta pertuturan secara sempit dan sesama manusia secara luas.

\subsubsection{Komponen Tutur Perilaku Kesantunan Berbahasa}

Dell Hymes (dalam Chaer dan Agustina 2010: 48) Suatu peristiwa tutur harus memenuhi delapan komponen, yang bila huruf-huruf pertamanya dirangkaiakan menjadi akronim SPEAKING.

1. (S) Setting and Scane (Latar) Setting berkenaan dengan waktu dan tempat tutur berlangsung, sedangkan scane mengacu pada situasi tempat dan waktu atau situasi psikologi pembicaraan.

2. (P) Perticipants (Peserta) adalah pihak-pihak yang terlibat dalam komunikasi, yakni penutur dan mitra tutur, penyapa dan pesapa atau pengirim dan penerima.

3. (E) End (Tujuan komunikasi), yakni merujuk pada maksud dan tujuan pertuturan.

4. (A) Act squence, (pesan yang ingin disampaikan) mengacu pada bentuk ujaran dan isi ujaran. Bentuk ujaran berkenaan dengan kata-kata yang digunakan, bagaimana penggunaanya dan hubungan antara apa yang dikatakan dengan topik pembicaraan.

5. (K) Key (Kunci) mengacu pada nada, cara dan semangat di mana suatu pesan disampaikan.

6. (I) Instrumentalities, yakni mengacu pada jalur bahasa yang digunakan, seperti jalur lisan, tertulis, melalui telegraf atau telepon.

7. (N) Norm of Interaction and interpretation, yaitu mengacu pada norma atau aturan berinteraksi. Misalnya, yang berhubungan dengan cara berinterupsi, bertanya dan sebagainya.

8. (G) Gendre, (Ragam, register), yakni mengacu pada jenis bentuk penyampaian, seperti narasi, puisi, pepatah, doa dan sebagainya.

\subsection{Bentuk-Bentuk Maksim}

\section{Kesantunan Berbahasa}

\subsubsection{Bentuk-bentuk Maksim Kesantunan}

Leech (dalam Sailan 2014: 17) dalam bukunya "Principles of Pragmatics", pada akhirnya mengajukan tujuh maksim kesantunan yang meliputi (1) maksim kebijaksanaan (tact maxim), (2) maksim kedermawanan (generosity maxim), (3) Maksim pujian (praise maxim), (4) maksim perendahan hati (modesty maxim), (5) maksim kesetujuan (agrement maxim), (6) maksim kesimpatian (sympaty maxim), (7) maksim Pertimbangan (consideration maxim).

a. Maksim kebijaksanaan (tact maxim) Maksim kebijaksanaan adalah mengamanatkan agar penutur memberikan keuntungan atau meminimalkan kerugian bagi mitra tutur ketika berkomunikasi. Karena itu penutur harus menunjukan keikhlasan berkorban terhadap mitra tutur. Sesungguhnya maksim kebijaksanaan ini dapat dilakukan oleh siapa saja, tanpa memandang status sosial. Tuturan yang termasuk dalam maksim kebijaksanaan, misalnya "Jika ada pekerjaan lain yang mendesak untuk Anda selesaikan, biar nanti saya yang akan melanjutkan perkuliahan dalam mata kuliah yang kita asuh bersama." 
b. Maksim kedermawanan (generosity maxim) Dalam maksim kedermawanan, penutur harus rela memaksimalkan kerugian pada diri sendiri. Dalam hal ini ditunjukkan oleh penutur atas kesdiaannya memberikan sesuatu yang menjadi miliknya kepada mitra tutur, agar mitra tutur menjadi tercukupi kebutuhannya. Maksim kedermawanan itu terlihat dalam tuturan, "Bila tidak cukup uangmu membeli buku ini biar nanti saya yang menambahkannya."

c. Maksim pujian (praise maxim) Maksim ini ditunjukkan oleh kesediaan penutur pada mitra tutur untuk memberi pujian atas keberhasilan dan kelebihan mitra tutur. Tuturan berikut ini melatih kita untuk santun terhadap mitra tutur lewat pujian, "Saya salut terhadap Anda yang begitu sabar dan tenang dalam diskusi tadi, walaupun Anda dihujani dengan berbagai pertanyaan yang sangat memojokkan."

d. Maksim perendahan hati (modesty maxim) Maksim perendahan hati ini ditunjukkan oleh upaya penutur untuk selalu memaksimalkan ketidakhormatan pada diri sendiri, dan meminimalkan pujian pada diri sendiri serta tidak menunjukkan prestasi yang telah di raih di hadapan banyak orang ketika menjalin konteks sosial. Ungkapan perendahan hati bermacam-macam bergantung pada referensi yang dimaksud. Misalnya dalam tuturan, "Silahkan dimakan, maaf seadanya." Atau dalam tuturan, "Prestasi ini adalah hasil kerja keras bersama, semoga apa yang kita capai menjadi bukti bakti kita pada negeri ini." e. Maksim kesetujuan (agrement maxim) Dalam maksim kesetujuan dicirikan oleh tercapainya kecocokan antara penutur dan mitra tutur. Di sini sikap konfrontasi diupayakan untuk dihindari, demi menjaga keharmonisan dengan mitra tutur. Contoh maksim kesetujuan ini misalnya, "Saya setuju dengan pendapat Anda karena apa yang Anda kemukakan memang ada benarnya, tetapi akan lebih baik jika pendapat itu dimintakan pendapat dari anggota peserta rapat lainnya,"

f. Maksim kesimpatian (sympathy maxim) Maksim ini diungkapkan dengan tuturan asersif dan ekspresif. Maksim kesimpatisan mengharuskan peserta pertuturan untuk memaksimalkan rasa simpati dan meminimalkan rasa antipati kepada mitra tutur. Jika mitra tutur mendapatkan kesuksesan atau kebahagian, penutur wajib memberikan ucapan selamat. Sebaliknya jika mitra tutur mendapat kesusahan, musibah, atau cobaan penutur layak ikut berduka, atau mengutarakan bela sungkawa sebagai tanda kesimpatian. Misalnya, "Saya bangga atas kesabaran Anda, sehingga maтри menyelesaikan studi tepat waktu, walaupun begitu banyak tantangan yang Anda hadapi."

g. Maksim Pertimbangan (consideration maxim) Maksim pertimbangan mengharuskan penutur untuk meminimalkan rasa tidak senang pada mitra tutur, dan memaksimalkan rasa senang pada mitra tutur. Penutur berkewajban meminta pertimbangan/saran dari mitra tutur jika ada hal-hal tertentu 
yang patut dipertimbangkan bersama. Biasanya dalam maksim pertimbangan dinyatakan dengan ungkapan bagaimana, dan sebaiknya, seperti terlihat dalam contoh berikut. "Bagaimana kalau spanduk ini dipasang di sebelah sini saja, karena di situ mengganggu keindahan kampus."

\subsection{Konsep Bahasa}

Bahasa mempunyai sistem yang sifatnya mengatur. Bahasa merupakan suatu lembaga yang memiliki polapola atau aturan-aturan yang dipatuhi atau digunakan (kadang-kadang tanpa sadar) oleh pembicara dalam komunitas saling memahami (Muhammad, 2016: 40). Kridalaksana (dalam Muhammad, 2016: 40) menyatakan bahwa bahasa adalah sistem lambang bunyi yang arbitrer yang digunakan oleh para anggota kelompok sosial untuk bekerja sama, berkomunikasi dan mengidentifikasi diri.

\subsubsection{Masyarakat Bahasa}

Masyarakat bahasa adalah sekelompok masyarakat yang merasa menggunakan bahasa yang sama. Dengan demikian, jika ada sekelompok masyarakat yang samasama menggunakan bahasa Sunda berarti mereka adalah kelompok masyarakat bahasa Sunda. Begitupun masyarakat lain yang menggunakan bahasa yang sama (Muhammad, 2016: 61). Hal ini sejalan dengan pendapat (Chaer 2012: 59-60) Masyarakat bahasa adalah sekelompok orang yang merasa menggunakan bahasa yang sama. Dengan demikian kalau ada sekelompok orang yang merasa samasama menggunakan bahasa Sunda, maka bisa dikatakan mereka adalah masyarakat bahasa Sunda; kalau ada sekelompok orang yang merasa menggunakan bahasa Mandailing, maka mereka bisa disebut masyarakat bahasa Mandailing; dan kalau ada sekelompok orang merasa menggunakan bahasa Inggris, maka mereka bisa disebut masyarakat bahasa Inggris.

\subsubsection{Variasi dan Status Sosial Bahasa}

Bahasa bervariasi karena anggota masyarakat penutur bahasa tersebut sangat beragam. Bahasa juga digunakan untuk keperluan yang beragam-ragam pula. Berdasarkan penuturnya, kita mengenal adanya dialek-dialek baik dialek regional maupun dialek sosial. Lalu berdasarkan penggunaanya, kita mengenal adanya ragam-ragam bahasa seperti ragam jurnalistik, ragam sastra, ragam ilmiah dan sebagainya (Muhammad, 2016: 62).

\subsubsection{Penggunaan Bahasa}

Dialek bahasa serta ragamnya digunakan di dalam dan oleh masyarakat. Ragam yang digunakan itu ditentukan oleh "kondisi" sekelompok orang menyatukan diri untuk mempertahankan dan membangun kehidupan. Misalnya kata kamu, anda, dan kau, dan variasi bahasa yang digunakan oleh masyarakat Indonesia atau menunjukan lawan atau mitra bicara. Secara sosial, ketiga kata ganti itu tidak dapat dipakai untuk menyapa lawan bicara. Bentuknya bervariasi, rujukannya sama (lawan bicara) bisa berbeda sesuai dengan usia, jenis, kelamin, status, dan hubungan sosial pembicara dengan lawan bicara. Hal yang berbeda ini disebut oleh penulis sebagai faktor sosial (Muhammad, 2016: 63). Sejalam dengan pendapat 
Muhammad setiap individu penutur memiliki cirri tuturan yang berbeda dengan penutur lain. Itulah sebabnya kita dapat mengenal seseorang lewat tuturannya meskipun tidal melihat si penutur itu (Soeparno, 2013: 57).

\subsubsection{Kontak Bahasa}

Kontak bahasa terjadi pada masyarakat terbuka. Melalui kontak itulah, masyarakat akan saling memengaruhi. Dengan kontak ini muncul bilingualisme dan multilingualisme. Selain itu mencul berbagai macam kasusnya seperti interferensi, integrasi, alih kode, dan campur kode. Topik akibat kontak bahasa ini, dapat menjadi objek penelitian bahasa yang maslah dan tujuannya dapat dirumuskan berdasarkan kerangka teori yang dipakai (Muhammad, 2016: 67).

\subsubsection{Bahasa dan Budaya}

Hipotesis oleh Edward Sapir dan Benjamin Lee Whorf (hipotesis SapirWhorf) (dalam Muhammad, 2016: 75). Menyatakan bahasa memengaruhi kebudayaan. Dengan kata lain, cara berfikir atau bertindak masyarakat penutur dipengaruhi oleh bahasa. Jadi, cara berfikir dan bertindak anggota masyarakat penutur dipengaruhi oleh bahasa. Maka, kebudayaan dan bahasa merupakan hal yang berbeda, tetapi sangat erat kaitannya dengan manusia yang memiliki kebudayaan (sistem berpikir dan bertindak) dan bahasa. Pikiran dan tindakan manusia sangat ditentukan oleh bahasa, yaitu sistem yang bunyi yang arbitrer untuk berkomunikasi.

\subsection{Bahasa Daerah}

Bahasa daerah adalah penamaan bahasa yang digunakan oleh kelompok orang yang anggota- anggotanya secara relatif memperlihatkan frekuensi interaksi yang lebih tinggi di antara mereka dibandingkan dengan mereka yang tidak bertutur dalam bahasa daerah tersebut (Masinambow dan Haenen, 2002: 52). Oleh karena frekuensi interaksi yang tinggi itu diwujudkan dalam ikatan institusional, seperti ikatan kekerabatan, upacara-upacara yang berkaitan dengan lingkaran hidup masing-masing warga, maka bahasa daerah dapat pula digunakan untuk kriteria pengidentifikasian dari suku bangsa atau kelompok etnis sehingga bahasa daerah juga dinamalakan bahasa suku bangsa.

\subsubsection{Kedudukan dan Fungsi Bahasa Daerah}

Adapun kedudukan dan fungsi bahasa daerah sendiri menurut La Ino (2015: 29) adalah sebagai berikut :

1. Kedudukan

Kedudukan bahasa daerah sendiri terbagi atas kedudukan resmi dan kedudukan tidak resmi. Kedudukan resmi bahasa daerah meliputi (a) bahasa pengantar di dalam pemerintahan, (b) bahasa pengantar, (c) bahasa pengantar di sekolah, dan (d) bahasa pengantar di dalam musyawarah. Adapun kedudukan tidak resmi dari bahasa daerah antara lain (a) bahasa pengantar dalam jual beli, (b) alat komunikasi dalam keluarga, (c) bahasa pengantar dalam obrolan, dan (d) bahasa pengantar dalam bercerita/berdongeng.

2. Fungsi

Adapun fungsi dari bahasa daerah adalah sebagai alat komunikasi luas suku bangsa, sebagai identitas suku bangsa, sebagai kebanggaan suku bangsa, dan sebagai behasa persatuan dan kesatuan. 


\subsubsection{Bahasa Wawonii}

Bahasa Daerah wawonii merupakan satu di antara jenis bahasa daerah yang ada di Negara Republik Indonesia. Bahasa Wawonii merupakan cabang dari Bahasa Austronesia, Bahasa Wawoniii masuk kedalam keluarga bahasa BungkuTolaki bersama dengan bahasa Mori dan bahasa Bungku di provinsi Sulawesi Tengah serta bahasa Moronene di Kabupaten Bombana, bahasa Kulisusu di Kabupaten Buton Utara, dan Bahasa Tolaki di jazirah tenggara pulau sulawesi. Berdasarkan pernyataan tentang pelestarian dan perlindungan bahasa daerah, maka perlulah diadakannya penelitian dan pengkajian yang sistematis mengenai bahasa tersebut. Keberadaan bahasa daerah Wawonii akan memberikan kontribusi penting terhadap pelestarian budaya bangsa. Bahasa Wawonii adalah bahasa daerah yang berada di wilayah Sulawesi Tenggaara. Bahasa tersebut digunakan oleh masyarakat Sulawesi Tenggara khususnya di Munse Kecamatan Wawonii Timur. Setiap masyarakat memiliki bahasabahasa daerah sendiri-sendiri sebagai unsur budaya dan cirri khas atau identitas masyarakat. Demikian halnya dengan masyarakat wawonii yang memiliki bahasa daerah yaitu Bahasa Wawonii sebagai salah satu identitas pendukung suatu budaya yakni kebudayaan wawonii (Melamba dkk, 2017: 254)

Penutur Bahasa Daerah Wawonii terbanyak, meliputi seluruh Kabupaten Konawe Kepulauan yang terdiri dari tujuh kecamatan yakni Kecamatan Wawonii Tengah, Kecamatan Wawonii Barat, Kecamatan Wawonii Timur, Kecamatan Wawonii Tenggara, Kecamatan Wawonii Timur Laut, Kecamatan Wawonii Utara dan
Kecamatan Wawonii Selatan. Dengan luas wilayah keseluruhan $86.58 \mathrm{Ha}$. Secara geografis, pulau wawonii dibatasi oleh selat Tolaki di sebelah barat, laut Banda di sebelah Timur dan Utara, serta Kabupaten Buton Utara di sebelah Selatan. Sedangkan jumlah penduduk sebanyak 11088 jiwa (Sultra dalam angka: 2003). La Ino, (2015: 18)

\section{METODE PENELITIAN}

\subsection{Jenis dan Metode Penelitian}

\subsubsection{Jenis Penelitian}

Jenis penelitian ini termasuk penelitian lapangan. Maksudnya peneliti turun langsung ke lapangan untuk memperoleh dan mengumpulkan data yang sesuai dengan masalah penelitian.

\subsubsection{Metode Penelitian}

Metode yang digunakan dalam penelitian ini adalah metode deskriptif kualitatif. Penelitian ini dikatakan penelitian kualitatif karena menggunakan kalimat untuk mendeskripsikan acuan tindak tutur bukan dengan angka-angka atau statistik.

\subsection{Data dan Sumber Data \\ 3.2.1 Data}

Data yang digunakan dalam penelitian ini adalah data bahasa lisan yang berupa tuturan-tuturan dalam berbagai peristiwa Bahasa Wawonii yang bersumber dari penutur asli bahasa Wawonii khususnya di Desa Munse Kecamatan Wawonii Timur Kabupaten Konawe Kepulauan.

\subsubsection{Sumber Data}

Sumber data dalam penelitian ini berasal dari beberapa informan yang merupakan penutur asli bahasa Wawonii yang berdomisili di desa Munse Kecamatan Wawonii Timur Kabupaten Konawe Kepulauan. 
Pengambilan lokasi penelitian tersebut disebabkan bahasa yang digunakan masyarakat setempat dalam berkomunikasi tidak memperhatikan pentingnya memahami kesantunan dalam berbahasa, prinsip kesantunan dalam berbahasa, dan konteks berbahasa Wawonii. Untuk menjaga kelestarian data dalam penelitian ini, maka yang menjadi informan adalah mereka yang memenuhi kriteria sebagai berikut:

1. Berjenis kelamin pria atau wanita;

2. Berusia antara 25-65 tahun (tdak pikun);

3. Orang tua, istri atau suami informan lahir dan dibesarkan di desa itu sertajarang atau tidak pernah meninggalkan desanya;

4. Berpendidikan maksimal tamat pendidikan dasar (SD-SLTP);

5. Berstatus sosial menengah (tidak rendah atau tidak tinggi) dengan harapan tidak terlalu tinggi mobilitasnya;

6. Pekerjaan bertani atau buruh;

7. Memiliki kebanggaan terhadap bahasanya;

8. Dapat berbahasa Indonesia; dan

9. Sehat jasmani dan rohani. (Mahsun, 2014: 141).

\subsection{Metode dan Teknik} Pengumpulan Data

\subsubsection{Metode Pengumpulan Data}

Adapun metode yang digunakan dalam penelitian ini yaitu metode cakap dan simak. Metode cakap berupa percakapan antara peneliti dengan informan dalam pengumpulan data penelitian. Sedangkan, metode simak digunakan untuk memperoleh data yang dilakukan dengan menyimak penggunaan bahasa lisan dari informan (Mahsun, 2014: 127).

\subsubsection{Teknik Pengumpulan Data}

Untuk memenuhi kriteria validitas, maka dalam pengumpulan data, peneliti menggunakan beberapa teknik, yaitu:

a. Teknik cakap semuka, yaitu, langsung mengetahui kondisi geografis setiap daerah pengamatan yang mungkin turut berperan bagi perkembangan isolek pada daerah pengamatan itu sendiri.

b. Teknik catat, yaitu langsung mencatat hal-hal yang membedakan bunyi-bunyi yang agak mirip dengan langsung memperhatikan organ-organ bicara yang digunakan untuk menghasilkan bunyi itu.

c. Teknik rekam, yaitu pengumpulan data yang dilakukan dengan cara merekam tuturan informan yang dapat mendukung pelaksanaan teknik catat, yaitu penyediaan bahan untuk pengecekan kembali bahan-bahan yang telah dicatat.

\subsection{Metode dan Teknik Analisis Data}

\subsubsection{Metode Analisis Data}

Dalam menganalisis data, penelitian ini menggunakan metode deskriptif. Artinya penelitian dilakukan seobjektif mungkin berdasarkan data yang ada. Rahmania (dalam Safitri 2007: 153).

\subsubsection{Teknik Analisis Data}

Teknik analisis data dilakukan dengan mengggunakan pendekatan sosiopragmatik, sebuah pendekatan yang menelaah tuturan-tuturan yang berkaitan dengan kondisi tertentu, kebudayaan-kebudayaan dan masyarakat yang memakai bahasa.

Data dalam diolah menggunakan teknik analisis secara kualitatif yaitu 
menganalisis maksim kesantunan berbahasa dalam percakapan masyarakat lingkungan Desa Munse Kecamatan Wawonii Timur. Analisis data dilakukan melalui tahapantahapan, sebagai berikut.

1. Transkripsi rekaman data, yaitu memindahkan data kedalam bentuk tulisan.

2. Klasifikasi data berdasarkan identifikasi data dan pengelompokan data yang sesuai dengan prinsip sopan santun berdasarkan permasalahan penelitian yang ada.

3. Interpretasi data yaitu suatu proses penafsiran data atau analisis data yang telah diklasifikasikan sesuai dengan prinsip-prinsip kesantunan.

4. Analisis data, tahap ini peneliti berusaha untuk menganalisis semua data yang terkumpul berdasarkan kesantunannya dan dirumuskan menjadi sebuah kesimpulan setiap pokok permasalahan.

\section{HASIL PENELITIAN DAN \\ PEMBAHASAN}

4.1 Pembahasan

\subsubsection{Maksim Kebijaksanaan}

Maksim

digambarkan dalam pernyataan berikut.

\section{Data}

Konteks. Tuturan ini terjadi saat dua orang sedang menjaga Om Una yang sedang sakit, saat itu waktunya sarapan sebelum Om Una minum obat. Tuturan ini terjadi pada pagi hari, yang menjaga Om Una adalah anak dan sepupunya.

Ki da lako monahu akono papamu, lakomo periou balipo kude mia dumagaio.
'Kalau hendak pergi memasak untuk bapakmu, pergilah dulu nanti saya yang menjaganya'

Dari hasil penelitian ditemukan satu tuturan yang memenuhi maksim kebijaksanaan. Adapun tuturannya, Ki da lako monahu akono papamu, lakomo periou balipo kude mia dumagaio 'Kalau hendak pergi memasak untuk bapakmu, pergi saja dulu nanti saya yang menjaganya'. Tuturan ini memenuhi maksim kebijaksanaan karena penutur berusaha membantu mitra tutur untuk menjaga bapaknya yang sedang sakit saat hendak mitra tutur akan memasak untuk bapaknya.

\subsubsection{Maksim Kedermawanan}

Maksim kedermawanan digambarkan dalam pernyataan berikut.

\section{Data}

Konteks: Tuturan ini terjadi di pasar malam saat mitra tutur hendak melihatlihat cincin tetapi ragu untuk membelinya karena uang yang dibawanya tidak cukup. Penutur dan mitra tutur memiliki hubungan keluarga yaitu sepupu.

Alaom koeya sinsi balipo kude mia tumiwaio doimu.

'Ambil saja cincin itu biar nanti saya tambahkan uang kamu'

$\begin{array}{rcr}\text { Dari } & \text { hasil } & \text { penelitian } \\ \text { ditemukan } & \text { satu tuturan yang }\end{array}$ memenuhi maksim kedermawanan, yaitu Alaom koeya sinsi balipo kude mia tumiwaio doimu 'Ambil saja cincin itu biar nanti saya tambahkan uang kamu' Tuturan ini dituturkan oleh dua orang yang bersepupu.

\subsubsection{Maksim Pujian}

Maksim pujian digambarkan dalam pernyataan berikut.

\section{Data}

Konteks: Tuturan ini dilakukan saat penutur dan mitra tutur usai bermain 
voli. Penutur adalah guru mitra tutur saat masih SMP.

Moikoho bela tonia pepoli, kotiwaikom motau montaha smesh.

'Permainan volimu tadi sangat bagus, makin pintar tahan smesh'

Dari hasil penelitian ditemukan satu tuturan yang memenuhi maksim pujian yaitu, Moikoho bela tonia pepoli, kotiwaikom motau montaha smesh 'Permainan volimu tadi sangat bagus, makin pintar tahan smesh'.

\subsubsection{Maksim Perendahan Hati}

Maksim perendahan hati digambarkan dalam pernyataan berikut.

Data

Konteks: Tuturan ini dilakukan saat persahabatan antara karangtaruna Desa Munse dan Desa Batulu. Persahabatan ini rutin dilakukan sebagai bentuk silaturrahim antar kedua desa, kegiatannya dalam bentuk pertandingan bermain bola dan makan bersama.

Mipongka taho mi petangkoro, mari mi sabara kanaiom dano.

'Dimakan makanannya jangan malu-malu, dimaklumi hanya seperti ini adanya'

Dari hasil penelitian ditemukan tuturan yang mengandung maksim perendahan hati yaitu, Mipongka taho mi petangkoro, mari mi sabara kanaiom dano 'Dimakan makanannya jangan malu-malu, dimaklumi hanya seperti ini adanya'. Maksim Kesetujuan

Maksim kesetujuan digambarkan dalam pernyataan berikut.

Data

Konteks: Tuturan ini dilakukan pada saat rapat karangtaruna membahas persahabatan antara Desa Munse dan Desa Batulu yang akan dilaksanakan. Hal ini biasa dilakukan jika warga dari desa yang lain seperti Desa Batulu telah datang terlebih dahulu melakukan persahabatan di Desa Munse.

Moiko kando leumo pesahabatan to Batulu oleono ahadi, mari totukana ira riou

mpendua oleo hapao sadiaando.

'Lebih baik tim Desa Batulu datang persahabatan hari minggu, tapi kita tanyakan kembali hari apa kesiapan mereka

Dari hasil penelitian ditemukan tuturan yang mengandung maksim kesetujuan yaitu, Moiko kando leumo pesahabatan to Batulu oleono ahadi, mari to tukana ira riou mpendua oleo hapao sadiaando.

'Lebih baik tim Desa Batulu datang persahabatan hari minggu, tapi kita tanyakan kembali hari apa kesiapan mereka' Penutur dan lawan tutur harus bisa memaksimalkan kecocokan di antara mereka.

\subsubsection{Maksim Kesimpatian}

Maksim kesimpatian digambarkan dalam pernyataan berikut.

\section{Data}

Konteks. Tuturan ini dilakukan saat Mama Fadli mendengar kabar perihal kepulangan Om Una kembali ke rumah setelah beberapa waktu di rawat di Rumah Sakit. Mama Fadli adalah tetangga Mama Fatma dan masih memiliki hubungan keluarga dengan Om Una.

Kai ehe wainto kai uru waraka, pempia hakom sumo i ruma saki.

'Semoga dia lekas sembuh, sudah berulang kali dia masuk Rumah Sakit'

Dari hasil penelitian ditemukan tuturan yang mengandung maksim kesimpatian yaitu, Kai ehe wainto kai uru waraka, pempia hakom sumo $i$ ruma saki 'Semoga dia lekas sembuh, sudah berulamg kali dia masuk Rumah

327 |Jurnal BASTRA (Bahasa dan Sastra), Vol. 4 No. 2, Edisi April 2019/e-ISSN: 2503-3875/ http://ojs.uho.ac.id/index.php/BASTRA 
Sakit' Tuturan akan terasa santun jika dapat menunjukkan sikap simpatinya yang tulus pada penutur lain.

\subsubsection{Maksim Pertimbangan}

Data maksim pertimbangan ditandai dengan pernyataan berikut.

Data

Konteks: Tuturan ini dilakukan pada saat rapat lanjutan penentuan tempat persahabatan oleh karangtaruna Desa Munse, diakhir rapat Ketua Umum Karangtaruna Desa Munse mengajukan opsi untuk kegiatan berikutnya.

Kanaampe kito sale ira karangtaruna hakono Lebo Raya kongko Tekonea raya persahabatan, kato perisosi mpendua mbule.

'Bagaimana kalau kita mengajak karangtaruna Lebo Raya dan Tekonea Raya persahabatan, agar bersatu kembali'

Dari hasil penelitian ditemukan tuturan yang mengandung maksim pertimbangan yaitu Kanaampe kito sale ira karangtaruna hakono Lebo Raya kongko Tekonea raya persahatan, kato perisosi mpendua mbule.

'Bagaimana kalau kita mengajak karangtaruna Lebo Raya dan Tekonea Raya persahabatan, agar bersatu kembali' Penutur berkewajiban meminta pertimbangan/saran dari mitra tutur jika ada hal-hal tertentu yang patut dipertimbangkan bersama.

\subsection{Relevansi Penelitian dalam Pembelajaran di Sekolah}

Kesantuan dalam berbahasa baik di lingkungan sekolah, masyarakat, maupun keluarga sangatlah penting, karena dengan bertutur dan berkomunikasi dengan santun dapat menjaga nilai diri sebagai makhluk sosial, pada dasarnya manusia adalah makhluk sosial, yaitu makhluk yang tidak dapat hidup sendiri tanpa bantuan orang lain. Agar kita dapat hidup bersama-sama dalam masyarakat dan diterima oleh masyarakat tersebut, maka kita juga harus dapat menyesuaikan diri dengan lingkungan sesuai dengan norma-norma dan nilainilai sosial dan saling menghormati yang dianut oleh masyarakat tersebut termasuk diantaranya nilai kesantunan dalam berbicara.

Kesantunan berbahasa merupakan kajian ilmu pragmatik. Dalam pragmatik, pengkajian bahasa didasarkan pada penggunaan bahasa bukan pada struktur semata, tapi juga konteks-konteks yang melingkupi suatu bahasa menjadi fokus perhatian dalam kaitannya dengan makna yang muncul dari suatu penggunaan bahasa.

Keterampilan bahasa yang meliputi menyimak, berbicara, membaca, dan menulis merupakan target dari pembelajaran bahasa. Melalui keterampilan menyimak, seseorang dapat memahami informasi dengan baik yang diperoleh secara lisan ataupun tulisan, sehingga tidak menimbulkan kesalahpahaman dalam berkomunikasi. Dengan keterampilan berbicara seseorang akan mampu menyampaikan informasi kepada orang lain atau lawan tutur dengan baik, sehingga lawan tutur dapat melakukan tindakan sesuai dengan apa yang disampaikan oleh penuturnya. Dengan keterampilan membaca, seseorang dapat membaca informasiinformasi tertulis baik melalui media cetak maupun media elektronik atau lambang-lambang yang digunakan dalam berkomunikasi secara lisan antara penutur dan mitr tutur. Keterampilan menulis, sesorang dapat menyampaikan informasi melalui 
media tulisan. Sehinggah, orang lain dapat memahami apa maksud yang terdapat dalam tulisannya.

Penelitian kesantunan berbahasa dalam masyarakat Desa Munse Kecamatan Wawonii Timur menerapkan 4 keterampilan berbahasa indonesia sebagaimana tercantum dalam buku mata pelajaran Bahasa Indonesia dengan kompetensi dasar berbicara,berwawancara dengan narasumber dari berbagai kalangan. Indikator pencapaiannya, siswa mampu melakukan wawancara dengan narasumber dari berbagai kalangan dengan memperhatikan etika berwawancara.

\section{PENUTUP}

\subsection{Kesimpulan}

Berdasarkan hasil penelitian yang dilakukan mengenai Kesantunan Berbahasa Wawonii di Lingkungan Masyarakat Desa Munse Kecamatan Wawonii Timur dapat disimpulkan bahwa kesantunana berbahasa di lingkungan Masyarakat Desa Munse Kecamatan Wawonii Timur menggunakan 7 maksim kesantunan berbahasa yaitu (1) maksim kebijaksanaan (tact maxim), maksim kedermawanan (generosity maxim), (3) Maksim pujian (praise maxim), (4) maksim perendahan hati (modesty maxim), (5) maksim kesetujuan (agrement maxim), (6) maksim kesimpatian (sympathy maxim), (7) maksim pertimbangan (consideration maxim), yang terdapat di lingkungan masyarakat Desa Munse dapat dilihat dari hasil penelitian yang dilakukan, bahwa ditemukan gambaran-gambaran penggunaan maksim berbahasa Wawonii di lingkungan Desa Munse Kecamatan Wawonii Timur. Lingkungan yang dijadikan objek penelitian tidak memperhatikan kesantunan pada saat berbicara antara penutur dan mitra tutur.

\subsection{Saran}

Saran yang dapat disampaikan dari hasil penelitian ini adalah:

1. Seluruh penutur Bahasa Wawonii di Desa Munse maupun penutur Bahasa Wawonii pada umunya agar selalu membiasakan menggunakan Bahasa Wawonii di lingkungam keluarga dan masyarakat dengan santun.

2. Generasi penutur Bahasa Wawonii di Desa Munse maupun penutur Bahasa Wawonii pada umumnya agar tetap bangga menggunakan Bahasa Wawonii di lingkungan keluarga maupun masyarakat.

3. Penelitian ini Penelitian ini masih jauh dari kesempurnaan dan hanya masih sebagian kecil saja tentang prinsip kesantunaan berbahasa, kerana masih banyak teori kesantunan yang dapat membahas lebih lagi mengenai kesantunan yang terdapat pada lingkungan masyarkat.

4. Penulis berharap penelitian mendatang lebih mendalam demi diperoleh hasil yang lebih memuaskan. Penulis menyadari bahwa penelitian ini masih jauh dari penjelasan yang mendalam secara pragmatik. Pembelajaran akan terus berproses dan tidak akan berhenti sampai disini. diteliti untuk dikemudian hari.

\section{DAFTAR PUSTAKA}

Chaer, Abdul. 2012. Linguistik Umum. Jakarta: Rineka Cipta.

Chaer, Abdul dan Leonie Agustina. 2010. Sosiolinguistik Perkenalan Awal. Jakarta: Rineka Cipta. 
La Ino. 2015. Deskripsi Fonem Bahasa di Sulawesi Tenggara. Yogyakarta: Pustaka Pultika.

Mahsun. 2014. Metode Penelitian Bahasa Tahapan Strategi, Metode, dan Tekniknya (Edisi Revisi). Jakarta: Raja Grafindo Persada.

Masinambow, E.K.M dan Paul Haenen. 2002. Bahasa Indonesia dan Bahasa Derah. Jakarta: Yayasan Obor Indonesia.

Melamba, Basrin, Muhammad Yani dan La Janu dkk. 2017. Sejarah Konawe Kepulauan. Yogyakarta: Istana Publishing.

Muhammad. 2016. MetodePenelitian Bahasa. Yogyakarta: Ar-Ruzz Media.

Rahardi, Kunjana. 2005. Pragmatik. Kesantunan Imperatif BI. Yogyakarta: Erlangga.

Rahardi, Kunjana. 2009. Sosiopragmatik. Yogyakarta: Erlangga.

Safitri, Sandra. 2007. "Modalitas Dalam Bahasa Muna". Dalam Bunga Rampai (hlm, 150-224). Kantor Bahasa Provinsi Sulawesi Tenggara.

Sailan, Zalili. 2014. Solidaritas dan Kesantunan Berbahasa, (Telaah Pragmatik): $\quad$ Pidato Ilmiah Pengukuhan Guru Besar. Universitas Halu Oleo.

Soeparno. 2013. Dasar-dasar Linguistik Umum (Edisi Kedua). Yogyakarta: Tiara Wacana.

Sudaryanto. 2015. Metode dan Aneka Teknik Analisis Bahasa Pengantar Penelitian Wahana Kebudayaan secara Linguistis. Yogyakarta: Sanata Dharma University Press.

Tarigan. 2015. Pengajaran Pragmatik. Bandung: Angkasa.

Yule, George. 2014. Pragmatik.

Yogyakarta: Pustaka Pelajar.

330 |Jurnal BASTRA (Bahasa dan Sastra), Vol. 4 No. 2, Edisi April 2019/e-ISSN: 2503-3875/ http://ojs.uho.ac.id/index.php/BASTRA 